W konferencji uczestniczyli przedstawiciele wielu środowisk naukowych kraju, m.in. KUL, Uniwersytetu Lódzkiego, Uniwersytetu Opolskiego, Uniwersytetu Szczecińskiego, WSP w Bydgoszczy, WSP w Częstochowie, WSP w Krakowie, WSP w Rzeszowie.

Konferencja rozpoczęła się obradami plenarnymi, podczas których analizowano zagadnienia dotyczące współczesnych problemów pedagogicznych, jak też zagadnienia podejmowane w przeszłości, będące obecnie ponownie przedmiotem żywych zainteresowan. Referaty wzajemnie się uzupetniały i dopetniały. Tę część obrad otworzył referat prof. dr hab. Teresy Kukołowicz (KUL), która zaprezentowała róże ujęcia personalizmu we współczesnej pedagogice polskiej, ich historyczne korzenie oraz dokonała ich porównania. Kolejny temat referatu pozostawał w kręgu problemów podejmowanych przez pedagogikę personalistyczną. Prof. dr hab. Katarzyna Olbrycht (UŚ) referując koncepcję rozwoju czlowieka jako osoby, uznała, iż osobowy wymiar edukacji może być szansą pokonania obecnego kryzysu oświatowego i wychowawczego. Kontrowersje wokół oceny ucznia przedstawiła prof. dr hab. Danuta Dryndowa (UŚ) w referacie pt. „Historyczne źródła współczesnych ofert w zakresie oceniania uczniów”. Znaczenie autodiagnozy nauczyciela $w$ procesie doskonalenia swych umiejętności zawodowych zreferowała prof. dr hab. Barbara Źechowska (UŚ). Obrady plenarne zamknął referat prof. dr hab. Danuty Koźmian (Uniw. Szczeciński), dotyczący teoretycznego i praktycznego dorobku samorządu uczniowskiego w Drugiej Rzeczypospolitej. Referentka wyeksponowała najwartościowsze elementy tego dorobku, które mogą być dzisiaj wykorzystane w poszukiwaniach koncepcji samorządu uczniowskiego.

Dalszy ciąg obrad toczył się w dwóch sekcjach. Sekcja pierwsza obradowała na temat „Współczesne teoretyczne i praktyczne oferty edukacyjne”. Wygłoszono 9 komunikatów i doniesień z badań.

Sekcja druga obradowała wokół historycznych źródeł współczesnej pedagogiki. Wygloszono 11 referatów i komunikatów, w większości przez młodych pracowników naukowych. Poszukując źródeł współczesnej myśli pedagogicznej referenci sięgali do odległych epok. W tym nurcie znalazły się referaty prof. dr hab. Juliusza Jundziłła ( $\mathrm{z}$ powodu nieobecności Profesora odczytanego przez dr K. Jakubiaka), w którym wydobyto aktualność rzymskich poglądów na problemy wychowania $w$ rodzinie oraz referat mgr llony Błaszczyk (WSP Bydgoszcz) ukazujący wklad L. A. Seneki w rozwój dydaktyki. Z kolei dr Robert Jankowski, przedstawiając poglądy Stanisława Konarskiego na wychowanie obywatelskie, wskazal na niewykorzystany dotąd dorobek pedagogów XVIII wieku w rozwiązywaniu problemów wychowania obywatelskiego.

Jednakże większość wystąpień dotyczyła okresu przelomu XIX i XX wieku (8 referatów). Spośród tych, pięciu referentów ukazało wkład polskich pedagogów w rozwój myśli pedagogicznej, podnosząc zarówno aktualność ich poglądów oraz możliwości twórczej adaptacji, jak też wskazując na nieznane i niewykorzystane obszary ich dorobku. W tym nurcie rozważan znalazły się referaty: dr Władysławy Szulakiewicz (WSP Rzeszów) omawiającej poglądy ,mistrza mistrzów polskiej pedagogiki” K. Twardowskiego, mgr Elżbiety Magiery (Uniw. Szczeciński) referującej koncepcję wychowania państwowego K. Sośnickiego, dr Andrzeja Gofrona (WSP Częstochowa) omawiającego pedagogikę kultury B. Nawroczyńskiego, mgr Anetty Wilhelm (Uniw. Szczeciński) ukazującej poglądy pedagogiczne H. Rowida oraz dr Marii Chymuk (WSP Kraków) analizującej nowatorstwo pedagogiczne J. Kulpy.

Pozostałe trzy referaty wygłoszone w tej części konferencji przedstawialy głównie praktyczny dorobek polskiej oświaty przełomu XIX i XX wieku. Dr Krzysztof Jakubiak (WSP Bydgoszcz) ukazał próby uspołecznienia szkoły od czasów nowożytnych po wiek XX. Mgr Beata Szczepańska (Uniw. Lódzki) zaprezentowała innowacje pedagogiczne podejmowane w Lodzi $w$ okresie międzywojennym. Obrady Sekcji zamknęło wystąpienie dr Grażyny Kempy (UŚ), która ukazała formy pomocy społeczno-wychowawczej kobietom bezrobotnym w woj. śląskim (1922-1939).

W drugim dniu konferencji w obradach plenarnych wygłoszono dwa referaty. Dr Bożena Sztumska (UŚ) przedstawila orientacje pedagogiczne neotomistów polskich lat międzywojennych, 
akcentując ich udział w kształtowaniu doktryny wychowawczej Kościoła. Dr Andrzej Pluta (WSP Częstochowa) ukazał źródła i proces kształtowania się pedagogiki pogranicza oraz wskazał na jej możliwości praktyczne - dydaktyczne i aksjologiczno-wychowawcze.

Konferencję zakończono ogólnym podsumowaniem obrad plenarnych i w sekcjach.

Agnieszka Stopinska-Pajak

\section{Forum Historyków Wychowania}

W dniach 18 - 20 października 1994 roku odbyła się w Obrzycku (w Domu Pracy Twórczej i Wypoczynku Uniwersytetu im. Adama Mickiewicza) ogólnopolska konferencja naukowa zorganizowana przez Zakład Historii Wychowania UAM i Sekcje Historii Wychowania Polskiego Towarzystwa Pedagogicznego. Zgromadziła ona liczne grono naukowców i bađaczy đziejów edukacji reprezentujących liczące się ośrodki naukowe w Polsce.

Tematyka konferencji dotyczyła, najogólniej rzecz biorąc, stanu i perspektyw historii wychowania jako swoistej dyscypliny naukowej $\mathrm{i}$ jako przedmiotu dydaktyki uniwersyteckiej. W tym kontekście wiele uwagi poświęcono także analizie aktualnego stanu i perspektyw rozwoju kadry naukowej w dziedzinie historii wychowania. W myśl założeń przyświecających organizatorom konferencji samo spotkanie miało odegrać pewną rolę w tym rozwoju, zwłaszcza młodszej generacji badaczy, a przede wszystkim stanowić próbę integracji tego śrođowiska historyków wychowania wokół pilnych w obecnej dobie zadań dydaktycznych i naukowych. Konferencja miała być dla tej kategorii historyków wychowania również okazją do wzajemnej wymiany doświadczeń naukowych i dydaktycznych, jak i pozyskania opinii profesorów obecnych na konferencji. Celom tym wychodziła naprzeciw przyjęta przez organizatorów formuła forum.

Moderatorami obrad plenarnych i zespołów roboczych byli: prof. dr hab. Mirosława Chamcówna (Uniwersytet Wrocławski), prof. dr hab. Jan Hellwig (Uniwersytet im. A. Mickiewicza), prof. dr hab. Juliusz Jundzilł (WSP w Bydgoszczy), prof. dr hab. Jadwiga Krzyżaniakowa (Uniwersytet im. A. Mickiewicza), prof. dr hab. Czesław Majorek (WSP w Krakowie) oraz dr Krzysztof Kabziński (WSP w Olsztynie) i dr Sławomir Sztobryn (Uniwersytet Lódzki). Wystąpienia tych osób, formułowane przez nich opinie i poglądy wywoływały duży rezonans wśród uczestników Forum, były przedmiotem żywej dyskusji (toczonej także podczas rozmów kuluarowych).

Część merytoryczną konferencji otworzyło wystąpienie prof. J. Hellwiga, który dokonał swoistej prezentacji poznańskiego środowiska historyków wychowania eksponując min. jego odlegle historyczne tradycje (J. Hellwig wygłosił także referat nt. „Międzynarodowa współpraca naukowa historyków wychowania - stan i perspektywy", w ostatnim dniu konferencji).

Dużym uznaniem uczestników konferencji cieszyły się zajęcia warsztatowe prowadzone przez prof. J. Krzyżaniakową (w sekcji poświęconej trendom badawczym i zasobom źródłowym w studiach nad historią wychowania do XVIII wieku, ze szczególnym jednak uwzględnieniem problemu zaprezentowanego osobiście przez prof. J. Krzyżaniakową: „Możliwości źródłowe i interpretacyjne mediewistyki”) i prof. Cz. Majorka (nt. „Warsztat badawczy historyka wychowania đziejów najnowszych").

Trzydniowym obradom konferencji naukowej towarzyszyła także skromna ekspozycja najnowszych publikacji z zakresu historii wychowania. Reprezentowane były w niej pozycje trzech oficyn wydawniczych (z Poznania, Lodzi i Olsztyna).

Podczas konferencji odbyło się również otwarte posiedzenie Sekcji Historii Wychowania PTP. 